\title{
Introdução à lógica de programação usando o Scratch: proposta de uma metodologia para crianças
}

\section{Camila Ishida de Lima*, Fernanda Maria Pereira Freire.}

\section{Resumo}

O trabalho teve a intenção de construir uma metodologia para a introdução de conceitos de programação de computadores para crianças de 6 a 8 anos de idade. Tal proposta metodológica, baseada na linguagem Scratch, parte de (i) achados na literatura; (ii) resultados decorrentes da aplicação da proposta com crianças da faixa etária alvo e, finalmente, (iii) resultados da apreciação de pesquisadores experientes na área de Informática na Educação sobre a metodologia. Escolhemos contextualizar as atividades de programação utilizando uma história já conhecida, a de João e Maria. Apostamos também no lúdico, por meio do desenvolvimento de um jogo. E, ainda, levamos em consideração a hipótese de que a leitura do código o Scratch - cujos termos aproximam-se da língua materna da criança - pode ajudar no entendimento de conceitos computacionais.

\section{Palavras-chave: \\ Pensamento computacional, Metodologia, Scratch.}

\section{Introdução}

Nos dias atuais é perceptível a presença da tecnologia na nossa sociedade que funciona como agente mediador entre as pessoas e os conhecimentos. A tecnogia afeta a sociedade, pois altera a forma como as pessoas se relacionam, trabalham e interagem umas com as outras (BONA, 2010). Podemos inferir que as crianças enxergam 0 mundo de forma diferente e que, provavelmente, isso influencia o modo como aprendem. Estamos diante de novos desafios quando pensamos em o quê e como "ensinar" à essas crianças.

A proposta é introduzir crianças de 6 a 8 anos à lógica de programação de maneira contextualizada e lúdica. Queremos tornar esse primeiro contato da criança algo divertido e prazeroso

\section{Resultados e Discussão}

Partimos de uma hipótese construcionista (PAPERT, 1980) que dá importância ao lúdico, ao universo infantil, à contextualização das atividades, a interação e a mediação no aprendizado.

Em relação ao lúdico, escolhemos formular um jogo. Consideramos que o jogo é tido como algo prazeroso que promove maior engajemento nas atividades que propõe. Em respeito ao universo infantil, decidimos utilizar uma história bastante conhecida na nossa cultura: João e Maria. A recontagem do conto contextualiza o jogo e os comandos usados em sua recontagem.

Quanto à interação e à mediação, entendemos que a criança, ao ler o código tendo como referência a história, pode construir uma ideia sobre o tipo de ação que ocorrerá, facilitada pela similaridade que há entre os nomes dos comandos do Scratch e a língua materna. Quando a criança vê a execução da linha de comando pode comparar com a ideia que inicialmente teve ao lê-lo. $\mathrm{E}$, assim, ao reler, a expectativa é a de que seja capaz de entender melhor seu funcionamento.

Foi com base nessas ideias que construímos 0 nosso "jogo". O jogo é composto de 5 cenas que recontam João e Maria. São atores: João, Maria, a Bruxa e o Lenhador. Em cada cena os atores executam ações relacionadas à história que são definidas por procedimentos do Scratch. Por exemplo, na Cena 1, João anda e joga pedaços de pão no chão. Além das cenas, criamos também cartas de desafio, em formato físico. As cartas se relacionam com o procedimento dos atores. No procedimento de andar e jogar pão de João, por exemplo, existe a carta "Faça João andar mais rápido" motivando a criança a mudar o código a fim de resolver o desafio.

A proposta metodológica prevê que um pequeno grupo de crianças (2 a 3) brinque com o jogo com o acompanhamento de mediadores. Inicialmente, apresentamos as cenas, lendo a história coletivamente e testando as ações dos personagens. Depois, volta-se à primeira cena para que as crianças possam interagir com o código: cada criança sorteia uma carta desafio. Lêem o códlgo, observam as ações na tela e tentam fazer as alterações no código para atender aos diferentes desafios propostos. Os mediadores devem ficar atentos a fim de intervirem quando necessário. A ideia é deixar as criancas livres para discutirem entre si e se ajudarem mutuamente. Depois de cada criança ter cumprido um desafio da cena, passa-se para a cena seguinte, repetindo o processo.

\section{Conclusões}

Ao aplicarmos a metodologia com crianças e expô-la para avaliação de pesquisadores, obtivemos resultados positivos. A dinâmica escolhida foi bem aceita e, a partir dos feedbacks recebidos, pudemos refinar nossa proposta metodológica. O trabalho, assim, concluiu com sucesso seus objetivos e a expectativa é poder contribuir com o debate sobre a importância do ensino de programação para crianças.

\section{Agradecimentos}

\section{Ao SAE/UNICAMP como a instituição de} fomento da pesquisa e ao NIED que deu a orientação e apoio necessário.

BONA, Viviane de. Tecnologia e Infância: Ser criança na contemporaneidade. 2010. Dissertação (Mestrado em Educação Matemática e Tecnológica) Centro de Educação, Universidade Federal de Pernambuco, Recife.

PAPERT, Seymour. Mindstorms: children, computers, and powerful ideas. United States of America: Basic Books: 1980. 